\title{
MIGRASI ORANG BALI KE BAYUNG LENCIR ${ }^{1}$
}

\author{
Efrianto. A \\ $B P N B$ PADANG \\ Jl. Raya Belimbing No. 16 A Kuranji Padang \\ efri_bpsnt@yaho.co.id
}

\begin{abstract}
Abstrak
Bali merupakan sebuah nama daerah dan suku bangsa yang memiliki keunikan tersendiri dibandingkan dengan suku bangsa lain di Indonesia. Salah satu keunikan mereka adalah kebiasaan dan identitas sosial mereka terlihat sangat jelas dari bentuk dan model rumah yang mereka miliki. Orang Bali dikenal sebagai salah satu etnis yang menganut agama Hindu, sebagai penganut agama Hindu mereka miliki simbol tersendiri yang terlihat sangat jelas dari berdirinya sebuah pura di depan rumah mereka. Kondisi ini dengan sendirinya menimbulkan keunikan dan perbedaan tersendiri ketika etnis ini jauh dari daerah asal mereka di Bali. Tulisan ini inggin menjelaskan tentang bagaimana kedatangan etnis Bali di Kecamatan Banyu Lencir Kabupaten Musi Banyuasin Propinsi Sumatera Selatan. Observasi lapangan menemukan data yang menarik tentang orang Bali di Banyu Lencir.
\end{abstract}

Kata kunci : Faktor Penarik, Kedatangan dan Kehidupan

\section{A. Pendahuluan}

Orang Bali merupakan salah satu etnis yang dipindahkan oleh pemerintah, baik karena bencana alam atau kepadatan penduduk tidak sebanding dengan luas wilayah. Dua alasan ini menyebabkan pemerintah harus memindahkan orang Bali ke luar dari daerah mereka. Orang Bali mendiam beberapa pulau yang terletak antara Pulau Jawa dan Lombok, kawasan ini terdiri dari beberapa pulau antara lain Pulau Nusa Penida, Pulau Nusa Lembongan, Pulau Nusa Ceningan, Pulau Serangan, Pulau Bali dan Pulau-Pulau kecil lainnya. Pulau Bali merupakan pulau terbesar di kawasan ini, hal ini yang menyebabkan daerah ini lebih dikenal dengan nama Propinsi Bali. (Profil Balai Wilayah Sungai Bali-Penida diambil http://www.pu.go.id)

Berbicara tentang kepindahan orang Bali ke luar dari propinsi mereka, dalam jumlah besar terjadi pada tahun 1953. Hal ini ditandai dengan dipindahkannya orang Bali ke Balitang. Kepindahan orang Bali dalam skala besar terjadi pada tahun 1963, ketika meletusnya Gunung Agung di Kabupateng Karangasem. Pasca meletus Gunung Agung, banyak lahan pertanian penduduk tidak bisa diolah dan digarap lagi, akibat lahar-lahar gunung berapi yang telah mengeras menjadi batu. ( Beritabali.com diposkan tanggal 06 Agustus 2012). Kondisi ini menyebabkan lahan pertanian menjadi sulit untuk dicangkul dan digarap untuk dijadikan lahan pertanian.

Kepindahan orang - orang Bali semakin banyak ketika pemerintah Orde Baru pada tahun 1972 menetapkan Pulau Jawa, Madura dan Bali sebagai daerah asal transmigrasi sedangkan Pulau Sumatera, Kalimantan, Sulawesi dan Papua sebagai lokasi penempatan (www.hukumonline.com,). Perpindahan orang Bali ke Sumatera menyebabkan di beberapa propinsi di Sumatera, terdapat daerah-daerah yang dihuni oleh orang Bali. Di Propinsi Sumatera Utara salah satu komunitas orang Bali dapat ditemukan di Desa Pegajahan, sekitar 12 Km dari 
kota Perbaungan, Sumatera Utara. Komunitas Bali di kawasan ini masih taat akan tradisi. walau jauh dari kampung halaman (Andri Nugraha, 2013:4).

Ketaatan dan kepatuhan orang Bali terhadap tradisi dan agaman mereka terlihat pada tahun 1989, masyarakat Bali di kawasan ini mendirikan sebuah Pura yang diberi nama Pura Panataran Dharmaraksaka yang fungsinya sebagai tempat ibadah umat Hindu Bali yang ada di desa tersebut (Andri Nugraha, 2013:7). Orang Bali juga ditemukan di Propinsi Bengkulu seperti di Kabupaten Muko-Muko dan Kabupaten Bengkulu Utara. Di Kota Arga Makmur Kabupaten Bengkulu Utara orang Bali di kawasan ini hidup satu desa dengan orang Islam, Kristen dan Protestan (Undri, 2013: 5). Hal ini membuktikan bahwa orang Bali memiliki kemampuan untuk beradaptasi dengan masyarakat lainnya.

Propinsi Sumatera Selatan merupakan salah satu kawasan yang banyak menerima orang Bali. Hal ini dibuktikan, banyaknya perkampungan Orang Bali di beberapa kabupaten di Propinsi Sumetra Selatan. Umumnya mereka tinggal berkelompok pada satu kawasan salah satunya adalah di Kecamatan Bayung Lencir Kabupaten Musi Banyuasin. Bali merupakan salah satu etnis dan suku bangsa di Indonesia yang memiliki perbedaan dengan masyarakat lain di Indonesia. Perbedaan itu terlihat jelas dari agama dan kebudayaan yang mereka anut. Di Indonesia satusatu daerah yang mayoritas penduduknya beragama Hindu adalah masyarakat Bali. Kehidupan Orang Bali sangat dipengaruhi oleh ajaran Hindu yang mewajibkan seluruh penganutnya untuk mencapai keseimbangan dan kedamaian lahir dan batin. Dalam ajaran agama, orang Bali mempercayai konsep Trimurti, yaitu wujud Brahmana (sang pencipta), wujud Wisnu (sang pelindung dan pemelihara), serta wujud Siwa (sang perusak). (Abdul Yani Suryadi, 2012 :61).

Ritual agama orang Bali membutuhkan sebuah tempat yang disebut pura dan tempat pemujaan roh leluhur disebut sangga. Panduan orang Bali dalam menjalankan kehidupan di dunia ini dituangkan dalam kitab suci agama Hindu yang dikenal dengan nama weda. Semangat kerja orang Bali, diakui oleh etnis-etnis lainnya dan mereka diakui sebagai masyarakat agraris. Ketika mereka bermigrasi ke daerah lain budaya, adat dan tradisi yang mereka milik tetap mereka bawa dan dipertahankan. Di sisi lain pada kawasan baru mereka hidup berdamping dengan etnis lain yang memilik agama, tradisi dan budaya yang berbeda dengan mereka. Pertemuan dua budaya atau lebih ini dengan sendirinya menimbulkan dinamika tersendiri yang menarik untuk diamati. Dalam konteks itu tulisan ini fokus menjelaskan migrasi orang Bali di Kecamatan Bayung Lencir Propinsi Sumatera Selatan terutama dari aspek kedatangan mereka dan interaksi mereka dengan penduduk disekitarnya.

\section{B. METODOLOGI}

Tulisan ini menggunakan metode penelitian sejarah. Penelitian sejarah dilakukan dengan metode penelitian perpustakaan (Library Research) dan penelitian lapangan (Field Research). Penulisanan sejarah terdiri dari tahap heuristik, kritik, interpretasi, dan historiografi. Tahap pertama heuristik, yaitu pengumpulan data yang bersifat primer maupun sekunder, yang terdiri dari data tulisan dan lisan. Tahap berikutnya adalah melakukan kritik terhadap data-data yang telah diperoleh baik kritik ekstern maupun intern, guna menjamin otensitas dan kredibilitas 
dari data. Setelah melalui tahap kritik, maka dilanjutkan dengan interpretasi, penafsiran data melalui analisa data untuk mengkategorikan data yang bersifat asli, palsu, dan sebagainya. Tahap terakhir adalah penulisan dari hasil analisa data yang sudah lulus uji sehingga tidak bersifat kontradiksi.

Di samping mengunakan metode penelitian sejarah, tulisan ini juga mengunakan pendekatan yang dikembangkan oleh Sartono Kartodirjo yaitu penulisan sejarah dengan pendekatan ilmu-ilmu sosial lainnya (Sartono Kartodirdjo, 1992:35). Secara rinci pendekatan yang digunakan oleh para penulis adalah pendekatan dalam ilmu sosiologi yang sesuai dengan permasalahan dan tujuan tulisan. Dalam disiplin sosiologi khususnya dikenal dua pendekatan yang popular digunakan, yaitu pendekatan kualitatif dan pendekatan kuantitatif. Pendekatan kualitatif merupakan metode penulisanan ilmu-ilmu sosial yang menganalisis data berupa katakata dan perbuatan-perbuatan manusia dengan cara interprestasi (Afrizal, 2008:45).

Untuk itu dalam penulisan ini dilakukan studi perpustakaan yang dilakukan ke Kantor Arsip, Perpustakan dan Dokumentasi Kabupaten Musi Banyuasin, Kantor Arsip Propinsi Sumatera Selatan, dan data yang pernah diperoleh di Perpustakaan Nasional RI, serta Arsip Nasional RI Jakarta. Data-data primer yang ditemukan berupa arsip-arsip dan dokumen yang menyangkut latar belakang kedatangan para transmigran ke Kecamatan Banyu Lencir, serta bagaimana proses pembebasan lahan yang dilakukan oleh pemerintah dan bagaimana persiapan yang dilakukan oleh pemerintah.

Dalam penelitian perpustakaan juga dicari sumber-sumber sekunder yang bisa menunjang penulisanan terkait, misalnya surat kabar lokal dan nasional serta website serta laporan penulisanan yang telah dilakukan oleh dinas-dinas terkait dan lembaga-lembaga lainnya. Sedangkan penulisanan lapangan dilakukan dengan metode wawancara, yang lazim dalam kajian sejarah kontemporer. Sejarah kontemporer menurut Nugroho Notosusanto adalah sejarah yang jarak kejadiannya relatif dekat dengan masa sekarang, sehingga para pelaku dalam suatu peristiwa banyak yang masih hidup dan bisa diwawancarai (Nugroho Notosusanto, 1984 : 6$8)$.

Wawancara telah dilakukan dengan tokoh-tokoh masyarakat Bali di Kecamatan Banyu Lencir. Wawancara juga dilakukan dengan tokoh masyarakat yang memiliki pengetahuan tentang proses kedatangan orang Bali dan tokoh masyarakat yang dipandang memiliki pengetahuan tentang tulisan yang sedang dibuat. Studi perpustakaan dan wawancara yang dilakukan diolah dan disusun untuk dijadikan tulisan.

Pendekatan yang digunakan dalam tulisan ini adalah pendekatan kualitatif dengan tipe deskriptif. Penggunaan pendekatan kualitatif deskriptif ini didasarkan pada beberapa keperluan penulisan dimana output penulisan ini diharapkan dapat memenuhi aspek intensitas data. Karena itu, diharapkan melalui pendekatan ini penulisan dapat memberikan gambaran terperinci mengenai sejauhmana kesepakatan gunung medan memberikan pengaruh terhadap adaptasi sosial budaya etnik Jawa terhadap penduduk lokal dan dengan itu dapat dilihat bagaimana bentuk-bentuk adaptasi etnik Jawa yang mereka lakukan hingga dapat keserasian hidup.

Jenis penulisanan yang dipakai dalam penulisan ini adalah bersifat deskriptif. Pendekatan 
deskriptif ini dikembangkan oleh penulisan dengan mengumpulkan data-data yang bersumber dari wawancara, catatan lapangan, foto-foto, dokumen pribadi, catatan dan memo serta dokumen resmi guna menggambarkan subjek penulisanan (Moleong, 1998: 6). Penulisanan dengan tipe deskriptif ini dimaksudkan untuk memperoleh gambaran mendalam, sistematis, faktual, dan akurat mengenai fakta serta hubungan antara fenomena yang diselidiki. Tujuannya yaitu untuk menggambarkan berlangsungnya kedatangan orang Bali ke Banyu Lencir.

\section{PEMBAHASAN}

\section{Perkampungan Orang Bali Di Sumatera Selatan}

Perpindahan orang Bali ke kawasan lain di Indonesia mulai dilakukan setelah kemerdekaan yaitu pada tahun 1953. berdasarkan data Kementerian transmigrasi dari tahun 1953 - 1968 jumlah transmigran yang berasal dari Bali mencapai $10.4 \%$ dari jumlah transmigran yang dipindahkan oleh pemerintah. Puncak dari berpindahnya orang Bali keluar dari Pulau Bali terjadi ketika meletusnya Gunung Agung. Pasca meletusnya Gunung Agung pada tahun 1963, tercatat hampir 12.000 orang Bali dipindahkan keluar dari Pulau Bali (Andry Geneton Hutapea, 2013 : 35-37). Selama periode 1953 -1968 pemerintah telah memindahkan Orang Bali ke berbagai pulau di Indonesia seperti terlihat dalam tabel di bawah ini:

\section{Tabel 4}

Lokasi Penempatan Orang Bali dari Periode 1953 -1968

Tabel 4 menjelaskan bawah pada periode 1953 - 1968 orang Bali paling banyak dikirim

\begin{tabular}{|r|c|r|r|}
\hline No & Pulau Tujuan & \multicolumn{1}{|c|}{ KK } & \multicolumn{1}{|c|}{ Jumlah } \\
\hline 1 & Sumatera & 8.556 & 35.124 \\
\hline 2 & Kalimantan & 333 & 1.357 \\
\hline 3 & Sulawesi & 1.096 & 5.204 \\
\hline 4 & Nusa Tenggara & 100 & 470 \\
\hline \multicolumn{2}{|c|}{ Total } & 10.085 & 41.854 \\
\hline
\end{tabular}

Sumber : Andry Geneton Hutapea : Kampung Bali di Desa Paya Tusam Kabupaten Langkat 1974 - 2002" diambil dari laporan Murial Charras dari Hutan Angker hingga tumbuh dewata, Transmigrasi di Indonesia, Yogyakarta. Gajah Mada University, hal 32

ke Pulau Sumatera dengan lokasi penempatan diberbagai propinsi di Sumatera. Sumatera Selatan merupakan salah satu daerah yang dijadikan lokasi penempatan transmigrasi di Pulau Sumatera. Proses perpindahan orang Bali ke Sumatera Selatan terus berlanjut pada tahun - tahun berikutnya. Kondisi ini menyebabkan pada saat ini sebagai besar kabupaten di Sumatera Selatan memiliki desa yang dihuni oleh orang Bali. Wawancara yang dilakukan dengan tokoh masyarakat Bali di Bayung Lencir diperoleh data bahwa orang Bali terdapat di Kabupaten Ogan Komering Ilir (OKI), Kabupaten Ogan Komering Ulu (OKU), Kabupaten Musi Banyuasin, Kabupaten Musi Rawas, Kabupaten Muara Enim dan Kabupaten Ogan Komering Ulu Timur (OKUT) (Ajisman dan Rois, 2012: 3 dan Yulianto, 2011: 70).

Proses kedatangan orang Bali ke Sumatera Selatan memiliki sejarah dan fenomena 
tersendiri. Perpindahan orang Bali dengan jumlah besar disebabkan meletusnya Gunung Agung pada tahun 1963. Letusan Gunung Agung menyebabkan beberapa daerah di Bali mengalami kerusakan, salah satu daerah yang paling parah adalah Kabupaten Karangasem (Wawancara dengan Wayan Made di Mendis pada tanggal 12 Desember 2014). Penduduk Kabupaten Karang Asam yang berada di lereng Gunung Agung harus dipindahkan karena lahan pertanian dan pemukiman mereka hancur akibat letusan Gunung Agung. Sebagaian besar penduduk yang berada di Lereng Gunung Agung merupakan petani sawah dan sebagian lagi berkebun. Letusan gunung menyebabkan banyak orang yang kehilangan harta benda bahkan nyawa. Masyarakat yang berada di sekitar Gunung Agung banyak yang kehilangan sanak keluarga seperti anak, istri atau suami (Wawancara dengan Sumandiyase di Bayung Lencir tanggal 10 April 2013).

Letusan gunung menimbulkan kerusakan dan keprihatian terhadap kehidupan masyarakat di kawasan Gunung Agung. Melihat kondisi masyarakat, pemerintah mengambil keputusan seluruh masyarakat yang terkena dampak letusan Gunung Agung harus diungsikan (ND Barus,2008:3). Kondisi ini menyebabkan masyarakat yang terkena dampak letusan Gunung Agung dingungsikan dan dikumpulkan di sebuah desa yang namanya Kubu Jadi Buleleng Kabupaten Singaraja. Setelah dikumpulkan di Desa Kubu Jadi seluruh masyarakat didata oleh petugas dari Jawatan Transmigrasi Kabupaten Karangasem.

Pemerintah melalui Jawatan Transmigrasi mengambil kesimpulan bahwa seluruh masyarakat korban letusan Gunung Agung harus dipindahkan ke daerah lain atau dikenal dengan istilah transmigrasi. Keputusan ini diambil karena lahan pertanian dan pemukiman mereka di lereng Gunung Agung tidak bisa dimanfaatkan lagi. Pendataan yang dilakukan oleh Jawatan transmigrasi menginformasikan bahwa jumlah korban letusan gunung Agung yang harus dipindahkan lebih kurang 12.000 jiwa. Oleh pemerintah, korban Gunung Agung dipindahkan ke Pulau Sumatera, Kalimatan dan Sulawesi (Muriel Charras, 1997 : 25).

Peristiwa inilah yang mendorong munculnya beberapa kawasan orang Bali di Sumatera, Salah satunya di Desa Nusa Bali Kecamatan Balitang. Transmigran yang dipindahkan ke Desa Nusa Bali diberangkatkan dengan kapal laut dari Pelabuhan Buleleng ke Pelabuhan Panjang Provinsi Lampung. Para transmigran diberangkatkan dengan kapal Tiongkok Cina. Transmigran yang berangkat banyak yang tidak lengkap, ada sebuah keluarga hanya terdiri dari kedua orang tuanya saja, atau ada juga yang tinggal hanya anak-anaknya. Kondisi ini menyebabkan ketika di kapal banyak transmigran yang stres, bahkan ada yang bunuh diri dalam perjalanan di dalam kapal". Setelah menempuh perjalanan selama tiga hari tiga malam, para transmigrasi diturunkan di Pelabuhan Panjang Provinsi Lampung. Perjalanan transmigran dari Bali ke lokasi pemukiman belum berakhir, sesampai di Pelabuhan Panjang para transmigran dikemahkan disana selama satu minggu. Mereka didata ulang oleh petugas Jawatan Transmigrasi Provinsi Lampung. Mereka yang dari Karangasem dibagi beberapa kelompok, sebagian melanjutkan perjalanan menuju Sumatera Selatan dan sebagain kelompok lagi tinggal di Lampung ( Ajisman Dan Rois,2012 : 45)

Kawasan orang Bali lainnya di Sumatera Selatan adalah di Kabupaten Muara Enim tepatnya di Desa Air Talas secara administrasi terletak di Kecamatan Rambang Dangku Kabupaten Muara Enim. Desa transmigran ini terbentuk sekitar tahun 1987, kehadiran mereka 
ke kawasan ini terkait erat demi suksesnya program transmigrasi yang saat itu merupakan salah satu program unggulan dari pemerintah dalam upaya pemerataan jumlah atau persebaran penduduk dan membuka lapangan kerja demi kesejahteraan masyarakat.

Kawasan transmigrasi Desa Air Talas adalah kawasan yang dihuni oleh berbagai etnik seperti Jawa, Sunda, Batak. Sedangkan orang Bali yang pindah ke kawasan ini adalah masyarakat yang mengalami kesulitan hidup di daerah asal. Umumnya transmigran yang pindah adalah orang yang tidak memiliki lahan pertanian atau masyarakat perkotaan yang sulit untuk bersaing menghadapi kerasan kehidupan di Pulau Bali (Abdul Yani Surya, 2012 : 67). Proses kepindahan mereka ke Desa Air Talas berbeda dengan Desa Nusa Bali. Mereka pindah melalui proses pendaftara ke Jawatan Transmigrasi di daerah asal mereka. Hal ini menyebabkan transmigran yang pindah dari Bali berasal dari berbagai kabupaten dan daerah di Bali. Cerita diatas mengambarkan bahwa orang proses terbentuknya perkampungan orang Bali di Sumatera Selatan ada yang disebabkan karena letusan Gunung Agung atau pindah untuk mensukseskan program pemerintah demi meningkatkan kehidupan masyarakat salah satunga melalui program transmigrasi.

\section{Faktor Pendorong}

Orang Bali bergerak dan mau pindah dari Pulau Bali ke kawasan lainnya termasuk ke Bayung Lencir dipengaruhi oleh faktor pendorong dan penarik mereka untuk pindah ke sana. Di antara faktor pendorong berkaitan dengan kondisi yang terdapat di daerah asal. Berbicara tentang migrasi orang Bali keluar dari Pulau Bali merupakan sebuah yang unik sebab secara budaya dan tradisi orang Bali memiliki perbedaan yang sangat jelas dengan penduduk dan suku bangsa lainnya di Indonesia. Perbedaan ini terlihat dari cirikhas orang Bali terlihat dari kebiasaan mereka membangun pura dan tempat ibadah di depan rumah setiap orang Bali (Wawancara dengan Wayan Arjane di Mendis pada tanggal 12 Desember 2012).

Keunikan orang Bali ini sesungguhnya di sadari baik oleh pemerintah, baik pemerintahan kolonial Belanda maupun Indonesia dan orang Bali sendiri. Transmigrasi telah dilaksanakan semenjak tahun 1905 yang ditandai dengan dipindahkannya orang dari Pulau Jawa ke Lampung atau Sumatera Bagian Selatan. Pada waktu bersama orang Bali, hanya dipindahkan oleh pemerintah kolonial Belanda dalam konteks transmigrasi lokal yaitu dipindahkanya orang Bali Selatan ke Bali Utara. Perpindahan ini dilaksanakan karena wilayah Bali Selatan lebih banyak didiami oleh penduduk karena tanahnya lebih subur dibandingkan Bali Utara. Pemerintah kolonial menyediakan 3000 hektar tanah di daerah Jembrana untuk dijadikan lokasi transmigrasi (Yulianto, 2011: 45-60). 
Gambar 1

Peta Pulau Bali

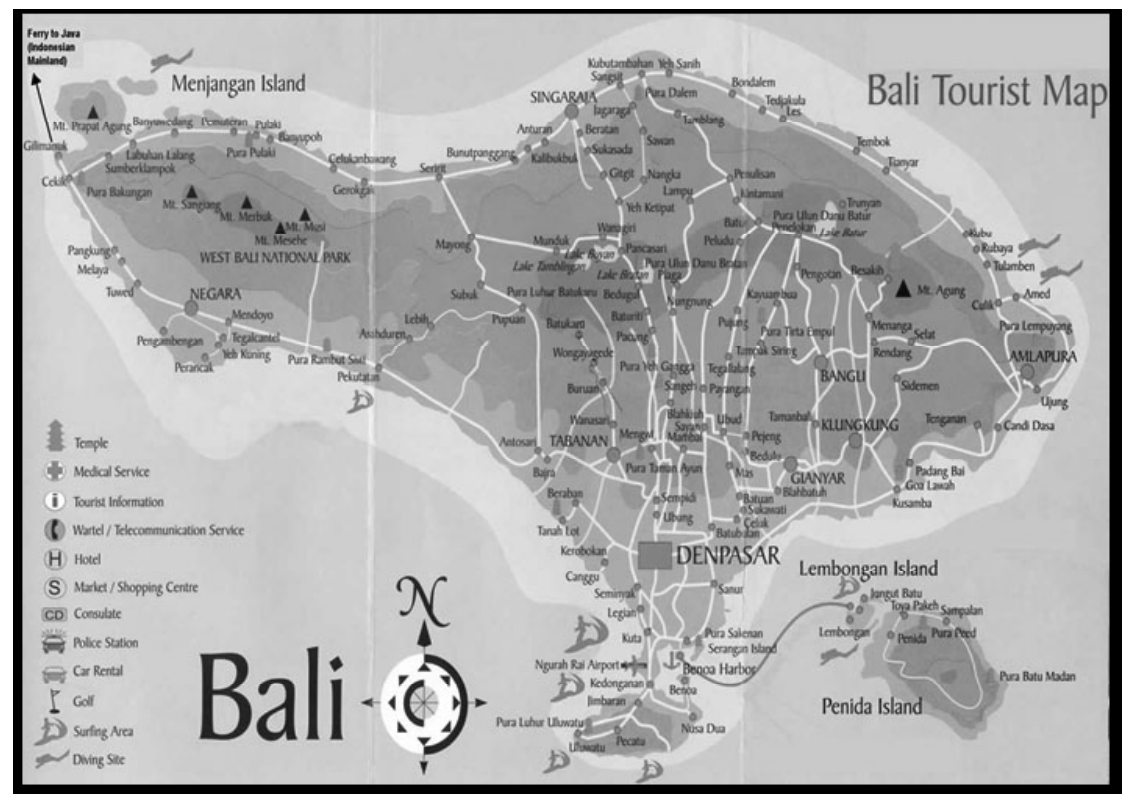

Sumber : http://adepratamapoetra.blogspot.com/2012/04/sejarah-ekologi-danekonomi-pulau-bali.html

Peta satu (1) menjelaskan bahwa kawasan Depasar sampai dengan kawasan Gilimanuk perbatasan dengan Pulau Jawa merupakan kawasan yang subur sehingga tingkat kepadatan penduduk dikawasan ini sangatlah tinggi. Sedangkan dari Depasar hingga Amalapura tergolong daerah yang kurang subur sehingga pemukimam masyarakat dikawasan ini relatif sedikit. Berbicara tentang migrasi penduduk dari Pulau Bali ke kawasan lain di Indonesia ada beberapa daerah yang dikenal sebagai daerah yang paling banyak penduduknya melakukan migrasi yaitu Pulau Nusa Penida dan pulau - pulau disekitarnya serta masyarakat perkotaan yang harus dipindahkan karena faktor kemiskinan yang melanda mereka (Yulianto, 2011: 45-60).

Pulau Nusa Penida dikenal sebagai daerah yang paling banyak penduduknya melakukan transmigrasi. Kondisi ini terkait erat dengan kondisi alam dan geografis kawasan tersebut. Pulau Nusa Penida dikenal sebagai kawasan yang tandus dan gersang, bahkan kawasan ini dikenal sebagai daerah yang tidak memiliki sungai. Akibatnya masyarakat hanya mengandalkan air hujan sebagai sumber utama untuk memenuhi kebutuhan air bersih. Terbatasnya air menyebabkan masyarakat di daerah pedalamam Pulau Nusa Penida menjadikan kawasan mereka untuk budi daya tanaman jagung, karena jagung tidak membutuhkan banyak air. Sedangkan bagi masyarakat yang berada di pesisir pantai, menjadi nelayan merupakan jenis usaha utama bagi mereka untuk memenuhi kebutuhan hidup (Yulianto, 2011: 45-60).

Fenomena kemiskinan juga ditemukan dikawasan lain di Pulau Bali terutama di daerah yang padat seperti di Denpasar, Tabanan dan beberapa daerah yang dikenal sebagai pusat ekonomi dan bisnis di Pulau Bali. Kepadatan penduduk dan terbatasnya jumlah lahan pertanian menyebabkan sebagian masyarakat di kawasan tersebut jatuh dalam kemiskinan. Kondisi ini mendorong pemerintah untuk memindahkan masyarakat dari kawasan ini ke kawasan lain di 
Indonesia (Wawancara dengan I Made Koster di Simpang Bayat, pada tanggal 13 Desember 2014).

Kepindahan orang Bali ke kawasan lain di Indonesia termasuk ke Bayung Lencir lebih banyak disebabkan oleh program transmigrasi. Arti dan rumusan transmigrasi telah diatur dalam Panca Matra Transmigrasi Terpadu, yaitu" Transmigrasi adalah perpindahan penduduk dari suatu daerah ke daerah yang lain dalam rangka pembentukan masyarakat baru untuk membantu pembangunan daerah, baik daerah yang ditinggalkan, maupun daerah yang didatangi dalam rangka pembangunan Nasional" (Martono 1979: 8). Dari rumusan tersebut dapat dijabarkan bahwa Transmigrasi adalah pemindahan penduduk dalam rangka pembentukan masyarakat baru untuk mempercepat pembangunan nasional serta bermanfaat bagi daerah asal dan daerah baru transmigran.

Transmigrasi yang merupakan upaya untuk mencapai keseimbangan penyebaran penduduk. Sehingga dengan beban tugas tersebut transmigrasi akan mampu memberikan dukungan kepada sektor-sektor lain demi pembangunan di Indonesia. Transmigrasi diharapkan bisa menciptakan perluasan kesempatan kerja, meningkatkan produksi dan meningkatkan pendapatan masyarakat (Martono 1979: 8). Untuk itu pemerintah melalui Undang-undang nomor 1 tahun 1973, telah menetapkan Pulau Bali sebagai salah satu daerah asal bagi para transmigran (http://hukum.unsrat.ac.id/uu/uu_1_1973.htm).

Undang tersebut tersebut merupakan jawab dari Undang-Undang No 3 tahun 1972 yang menjelaskan tentang berbagai alasan dan pertimbangan untuk menetapkan sebuah daerah dijadikan daerah asal transmigrasi. Masalah sosial, ekonomi dan pertahanan-keamanan serta atas usul menteri sebuah daerah dapat ditetapkan sebagai daerah asal dengan keputusan Presiden (http://hukum.unsrat.ac.id/uu/uu_1_1973.htm). Pertimbangan sosial, ekonomi dan pertahanan keamanan yang dimaksud dalam undang-undang No 1 tahun 1972 adalah kepadatan penduduk dan lapangan kerja yang sangat sempit. Luas areal tanah pertanian yang sangat terbatas. Jenis kesuburan tanah yang tidak menguntungkan dan adanya bencana alam dan gangguan keamanan.

Orang Bali yang dipindahkan ke Bayung Lencir umumnya disebabkan karena pertimbangan sosial dan ekonomi. Umumnya mereka pindah karena kesulitan hidup dan tidak adanya lahan pertanian yang dimiliki menyebabkan mereka menjadi miskin. Walaupun tidak bisa dipungkiri bahwa ada juga orang Bali yang pindah atau bertransmigrasi karena faktor becana alam seperti yang terjadi pada transmigrasi akibat letusan Gunung Agung.

Berbicara tentang proses kepindahan orang Bali ke luar Pulau Bali Pertama kali terjadi pada tahun 1953, jauh sebelum pemerintah menetapakn Pulau Bali sebagai daerah asal transmigrasi. Semua transmigran yang dipindahkan pada tahun 1953 dipindahkan ke Balitang Sumatera Selatan (Yulianto: 2011: 457). Tahun 1953, merupakan cikal bakal dari pindahanya orang Bali ke luar dari Pulau Bali. Proses kepindahan orang Bali terus berlanjut hingga saat ini. Kondisi ini yang menyebabkan orang Bali saat ini terdapat di beberapa propinsi di Pulau Sumatera dan membuat sebuah perkampungan Bali yang unik dan memiliki cirikhas tersendiri.

Kepindahan orang Bali ke luar dari Pulau Bali, disebabkan oleh berbagai faktor pendorong Ada beberapa hal yang mendorong mereka untuk melakukan transmigrasi diantaranya : 
1 Tingkat Kepadatan Penduduk didaerahnya (daerah asal). Sensus penduduk tahun 1971 menginformasikan bahwa penduduk Indonesia saat itu berjumlah 119 juta jiwa. Enam puluh lima (65) \% dari jumlah penduduk mendiami pulau Jawa dan Bali, kondisi ini jelas tidak sebanding dengan luas wilayah di Pulau Jawa dan Bali.

2 Kepadatan Penduduk menyebabkan terbatasnya lahan pertanian, sehingga menyebabkan kemiskinan bagi sebagian masyarakat. Kemiskinan menjadi momok yang menakutkan bagi masyarakat Indonesia. Padahal Indonesia merupakan salah satu negara yang kaya akan sumber daya alam.

3 Usaha Pemerintah untuk mengoptimalkan daerah-daerah yang subur dengan sumber daya alam, namun sedikit sumberdaya manusia yang menggarapnya. Untuk itu pemerintah berusaha untuk memindahkan penduduk dari wilayah yang padat ke kawasan tersebut.

4 Terbatasnya lahan pertanian untuk digarap sehingga kehidupan petani menjadi miskin. Seorang petani dapat dikatakan sebagai petani apabila memiliki lahan yang menjadi garapannya, jika tak ada lagi lahan yang dapat ia garap maka ia tidak lagi dapat dikatakan sebagai seorang petani.

5 Keingginan dari dalam diri masyarakat untuk memiliki lahan sendiri. Keinginan untuk memiliki lahan sendiri bertujuan untuk mendapatkan penghasilan yang tetap menjadi salah satu alasan yang mendasar untuk melakukan transmigrasi.

6 harapan bahwa dengan melakukan transmigrasi mereka akan mempunyai penghidupan yang lebih baik dengan iming-iming mereka akan diberikan tanah untuk persawahan dan perumahan dari pemerintah.

7 Keberhasilan transmigran terdahulu memberikan daya tarik terhadap calon transmigran baru, sebab mereka berharap dapat berhasil sama seperti pendahulunya (diolah dari Yulianto: 2011, Ajisman dan Rois, 2012 dan Hilda, 2009).

Faktor - faktor pendorong diatas yang menjadi alasan utama dari masyarakat Bali meninggalkan kampung halamanya. Kemiskinan yang dihadapi oleh Masyarakat Bali terutama bagi mereka yang berasal dari daerah yang padat dan memiliki kasta yang rendah menjadi alasan utama mereka pindah dari Pulau Bali mencari daerah baru. Potret kemiskinan dibeberapa daerah di Pulau Bali tergambar jelas dari tulisan Yulianto yang menjelaskan tentang Indentitas Kebalian di Lampung. Tulisan ini mengambarkan tentang bagaimana kondisi masyarakat Bali di Nusa Penida sebuah pulau yang banyak melahirkan para transmigran baik di Lampung maupun di Sumatera Selatan (Yulianto: 2011:236).

Observasi lapangan menemukan data bahwa orang Bali yang terdapat di Bayung Lencir merupakan orang Bali yang pindah pada tahun 1980-an mereka pindah dari berbagai daerah di Pulau Bali (Wawancara dengan Wayan Made di Mendis pada tanggal 12 Desember 2014). Umumnya para transmigran yang pindah melalui proses tranmigrasi swakarsa yaitu sebuah 
program pemindahan penduduk atas kemauan transmigran itu sendiri. Ada beberapa sebab mereka setuju pindah ke wilayah baru seperti dorongan kemiskinan, keinginan merantau untuk mengetahui daerah baru dan sebagainya. Sebab kondisi alam dan kehidupan sulit menyebabkan mereka setuju untuk pindah. Hal ini dapat dilihat dari hasil wawancara dengan para transmigran.

“... di Bali kehidupan kami sangat susah. kami tidak memiliki tanah pekarangan untuk diolah, hidup kami mengandalkan mencari kayu bakar dari hutan, kemudian kami jual ke penduduk. Uang yang pas-pasan tersebut kami gunakan untuk keperluan membeli beras ... "( Wawancara dengan I Gusti di Desa Mendis pada tanggal 12 Desember 2014)

“... di kampung dulu, saya numpang di rumah mertua saya dan bekerja serabutan untuk menghidupi istri saya. Teman - teman bercerita ada program transmigrasi ke Sumatera. Karena ingin merubah hidup dan hidup mandiri serta memiliki tanah dan tinggal dirumah sendiri, saya mencoba mendaftarkan diri beserta keluarga saya ... " (Wawancara dengan I Gusti di Desa Mendis pada tanggal 12 Desember 2014).

“... Keingginan untuk merubah nasib, sebab banyak saudara yang telah pergi bertransmigrasi ternyata ketika pulang ke Bali mereka hidup jauh lebih baik dari kami di kampung. Kondisi ini mendorong kami untuk mendaftar untuk mengikuti program transmigrasi (Wawancara dengan Wayan Made di Desa Mendis pada tanggal 12 Desember 2014).

“.... Upaya untuk mendapatkan lahan pertanian baru, sebagai anak transmigrasi yang telah merasakan nikmat dan sukses ketika di daerah tranmigrasi mendorong mereka untuk pulang ke Bali dan mendaftar menjadi peserta transmigrasi sehingga memiliki kesempatan untuk mendapatkan lahan pertaninan baru (Wawancara dengan Wayan Arjane di Bayat Ilir pada tanggal 13 Desember 2014).

Inforamsi lapangan tersebut menjelaskan bahwa orang Bali bersedia pindah ke daerah lain karena kesulitan hidup, keingginan untuk merubah nasib dan strategi mereka untuk mendapatkan lahan pertanian baru. Faktor inilah yang menyebabkan mereka berani meninggalkan kampung halamannya dan menjalani kehidupan di daerah yang baru yang belum pernah mereka datangi. Di samping itu faktor penarik yang menyebabkan orang Bali mau bertransmigrasi adalah adanya faktor penarik yang terdapat di daerah penampungan atau lokasi transmigran. Faktor penarik dari daerah penempatan biasanya didapatkan transmigrasi melalui informasi dan sosialisasi tentang manfaat transmigrasi. Informasi dan sosialisasi ini biasanya dilakukan oleh pemerintah melalui dinas terkait seperti Jawatan Transmigrasi dan TVRI.

Informasi Tentang Transmigrasi tertuang dalam pasal 25 Peraturan Pemerintah Republik Indonesia No. 42 Tahun 1973 Tentang Penyelenggaraan transmigrasi yang menyebutkan bahwa untuk menjadi transmigran wajib memenuhi beberapa syarat-syarat: warga negara Republik Indonesia, berkelakuan baik, berbadan sehat, sukarela, mempunyai kemampuan dan keterampilan kerja, tunduk dan patuh pada peraturan-peraturan tentang penyelenggaraan transmigrasi. ${ }^{2}$

Pemerintah membuat strategi penerangan yaitu memberikan pengertian umum kepada masyarakat akan arti pentingnya transmigrasi dalam pembangunan bangsa, sehingga dengan

\footnotetext{
${ }^{2}$ Transmigrasi merupakan program pemerintah sehingga aturan dan pedoman dalam menjalankan program ini disusun secara lengkap dan terukur oleh pemerintah.
} 
demikian diharapkan masyarakat dapat menyakini bahwa transmigrasi merupakan salah satu alternatif Jawaban memerangi kesulitan hidup terutama di daerah yang terkena / terancam bencana alam, daerah kritis dan tandus, daerah yang padat penduduknya serta di daerah yang terkena pembangunan proyek-proyek

Kegiatan penerangan transmigrasi ini memerlukan kerjasama antara pihak transmigrasi dengan instansi-instansi lainnya, misalnya Dinas Penerangan Daerah, para Pamong Desa maupun tokoh-tokoh masyarakat. Dengan demikian kebijaksanaan program transmigrasi lebih dikenal dalam masyarakat. Agar penerangan dapat menjangkau masyarakat luas maka penerangan transmigrasi dilaksanakan dengan sistem langsung maupun tidak langsung. Yang dimaksud secara lansung yaitu penerangan dilakukan oleh petugas-petugas penerangan transmigrasi dalam masyarakat. Misalnya melalui rapat-rapat desa, sarasehan dan kelompok-kelompok yang ada dalam masyarakat.

Informasi tidak langsung yaitu penerangan yang dilaksanakan melalui saran media massa maupun tokoh-tokoh masyarakat. Misalnya melalui anjangsana tokoh-tokoh masyarakat, beritaberita pembangunan lewat Televisi Republik Indonesia (TVRI), surat kabar, pertunjukan rakyat, pameran pembangunan, dan sebagainya. Kondisi tersebut memberikan dampak kepada masyarakat bahwa dengan bertransmigrasi kehidupan mereka jauh lebih baik dari pada bertahan di Bali.

Di samping itu pemerintah juga melakukan sosialisasi tentang bagaimana kehidupan yang akan dijalani oleh para transmigrasi dan bagaimana kondisi alam daeran baru. Menurut informasi dari transmigran mereka dikumpulkan di balai desa bahwa di Bayung Lencir akan mendiami sebuah daerah baru yang subur dan bagus, penduduknya diberi makan dan kebutuhan hidup selama 1 tahun ditanggung oleh pemerintah, daerah tersebut ditanami berbagai macam jenis tanaman, tanahnya luas, dan bila kita tetap bertahan didaerah tersebut maka kehidupan kita akan berubah menjadi baik.

Informasi lapangan menjelaskan bahwa masyarakat Bali yang akan di pindahkan ke Desa Mendis dan Bayat Ilir dijanjikan oleh pemerintah akan diberikan lahan yang siap untuk di tanam padi. Kondisi ini terkiat erat dengan kebiasaan mereka yang umumnya adalan petani. Kenyataan lapangan yang mereka temukan adalah sebuah kawasan yang baru dibuka dan belum siap untuk diolah sebagai mana mestisnya.

\section{Proses Kedatangan Transmigrasi}

Kedatangan orang Bali ke Bayung Lencir terutama desa Bayat Ilir dan Mendis. Melalui proses yang cukup panjang, mulai dari pendaftaran menjadi transmigran hingga proses keberangkatan ke wilayah tersebut. Informasi lapangan di Desa Bayat Ilir menjelaskan bahwa rombongan Bali pertama kali datang ke Bayat Ilir pada tahun 1986. Rombongan dari Bali yang pertama kali datang berjumlah $60 \mathrm{KK}$ dengan rincian $25 \mathrm{KK}$ dari Kabupaten Jimbrana, $10 \mathrm{KK}$ dari Nusa Penida dan $25 \mathrm{KK}$ Bali yang berasal dari Lampung (Wawancara dengan Wayan Arjane di Bayat Ilir pada tanggal 13 Desember 2014). 
Informasi tersebut menjelaskan bahwa orang Bali yang datang ke Bayat ilir berasal dari berbagai tempat di Pulau Bali, bahkan ada orang Bali yang selama ini tinggal di Lampung, namun kembali ke Bali dan mendaftar di Jawatan Transmigrasi. Wayan Arjena salah seorang transmigrasi dari Pulau Bali yang ada di Bayat Ilir menjelaskan bahwa ketika mereka di masih di Bali, pegawai Jawatan Transmigrasi sering datang dan berkunjung-kunjung ke desa-desa. Petugas tadi mendata setiap penduduk yang berminat untuk bertransmigrasi, bagi yang berminat silahkan mendaftar. Waktu itu, tahun 1986 saya baru menyelesaikan pendidikan di Universitas Udayana jurusan ekonomi dan telah bekerja di Koperasi Unit Desa (KUD) di Nusa Penida (Wawancara dengan Wayan Arjane di Bayat Ilir pada tanggal 13 Desember 2014).

Pekerjaan sebagai petugas KUD menyebabkan mengetahui kondisi masyarakat di Pulau Nusa Penida. Waktu itu dia mengambil kesimpulan untuk meningkatkan taraf hidup maka harus keluar dari Nusa Penida. Kondisi ini menyebabkan setiap gaji yang didapat selalu di tabung di KUD tempat bekerja. Pada awal tahun 1986, KUD tempat bekerja bangkrut sehingga uang tabungan tidak bisa kembali. Kondisi ini menyebabkan Wayan Arjena memilih bertransmigrasi sebagai salah satu langkah untuk meningkatkan taraf kehidupannya (Wawancara dengan Wayan Arjane di Bayat Ilir pada tanggal 13 Desember 2014).

Keberangkatannya ke Bayat Ilir adalah atas kemauan sendiri walaupun orang tua tidak setuju dia pindah dan ikut transmigrasi. Sebagai tenaga terdidik dia diperintahkan oleh kepala desa untuk mengajak orang kampung agar berminat mendaftar dan untuk ikut transmigrasi. Akhirnya bersama rombongannya dari kampung kami terdapat $4 \mathrm{KK}$ yang pindah bersama saya ke Bayat Ilir (Wawancara dengan Wayan Arjane di Bayat Ilir pada tanggal 13 Desember 2014).

\section{Gambar 6}

Wayan Arjane Ketua Perisada di Bayat Ilir

Informasi yang berbeda di dapat dari keluarga Bapak Made Pastike yang menjelaskan bahwa sesungguhnya keluarga besar mereka tidak lagi berada di Bali, namun di Lampung.

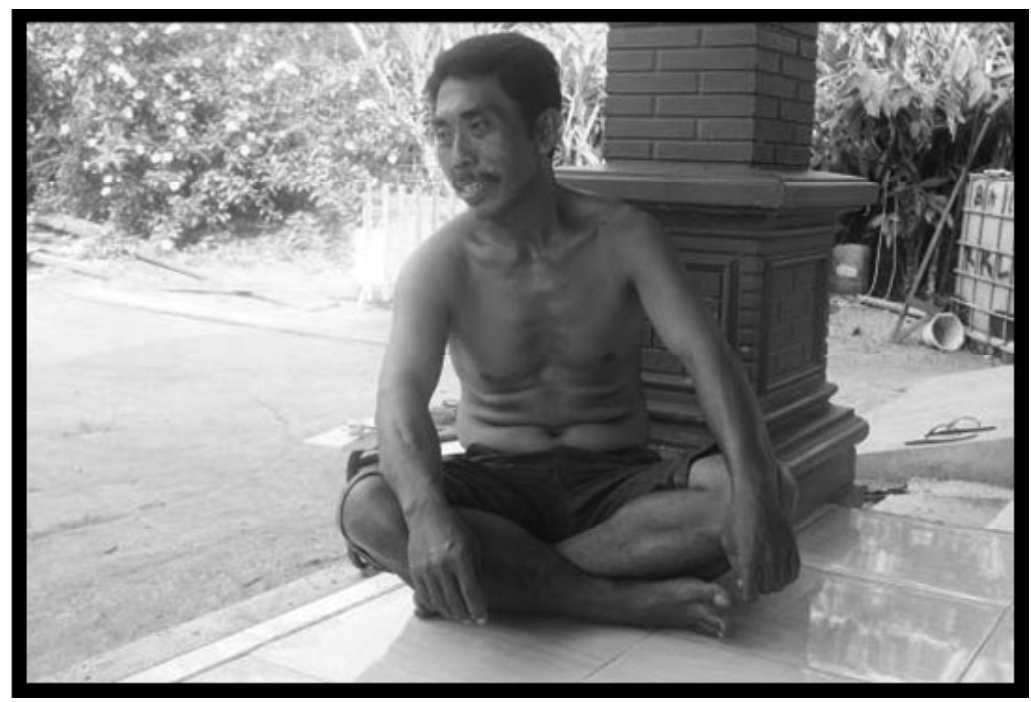

Sumber : dokumen Pribadi 
Masyarakat Bali dimanapun berada selalu rutin untuk berkomunikasi atau pulang ke Pulau Bali. Di saat mereka sedang berada Bali, kepala desa menyampaikan bahwa saat ini pemerintah sedang mencari masyarakat yang mau dan bersedia untuk mengikuti program transmigrasi. Informasi ini dimanfaatkan oleh Made Pastike untuk mendaftar dan menjadi anggota transmigrasi ke Bayat Ilir (Wawancara dengan Made Pastike di Bayat Ilir pada tanggal 13 Desember 2014).

Informasi dari Wayan Arjane dan Made Pastike tadi menjelaskan bahwa orang Bali yang berangkat pindah ke Bayat Ilir adalah orang-orang yang atas kesadaran sendiri untuk pindah dan mengikuti transmigrasi alasa utama yang menjadi alasan mereka adalah keingginan untuk merubah nasib dan merasakan kesuksesan seperti orang Bali yang telah terlebih dahulu mengikuti program transmigrasi.

Semua mereka dikumpulkan oleh Jawatan Transmigrasi Propinsi Bali dan diberikan pelatihan dan pembekalan yang diharapkan akan membantu mereka ketika sampai dilokasi penempatan. Rombongan ini berangkat dari Bali dengan menaiki kapal laut dari Bali langsung ke Boom Baru di Kota Palembang. Setelah itu rombongan menginap di wisma transito di Kota Palembang. Keesokan harinya rombongan di berangkat dari Palembang ke lokasi penempatan di Bayat Ilir (Wawancara dengan Wayan Arjane di Bayat Ilir pada tanggal 13 Desember 2014).

Rombongan dari Bali yang dikirim oleh pemerintah ke Bayat Ilir bersamaan datangnya dengan rombongan transmigrasi dari Jawa. Saat itu jumlah rombongan dari Bali berjumlah 60 KK sedangkan dari Jawa 40 KK (Wawancara dengan Wayan Arjane di Bayat Ilir pada tanggal 13 Desember 2014). Setiap KK mendapatkan sebuah unit rumah yang disediakan oleh pemerintah untuk ditinggali transmigran. Rumah yang diberikan adalah rumah seluas 6 x $6 \mathrm{M}$ dengan atap Seng, dinding papan, dan lantai seng. Pada saat itu pemerintah membangun 100 rumah untuk ditinggali oleh tranmigran.

\section{Gambar 7}

Model Rumah Pemberian Pemerintah untuk Transmigran

Jarak antara rumah yang satu dengan rumah yang lainnya adalah 50 meter. Untuk akses jalan pemerintah terlebih dahulu membuat aturan sehingga setiap rumah akan saling terhubung.

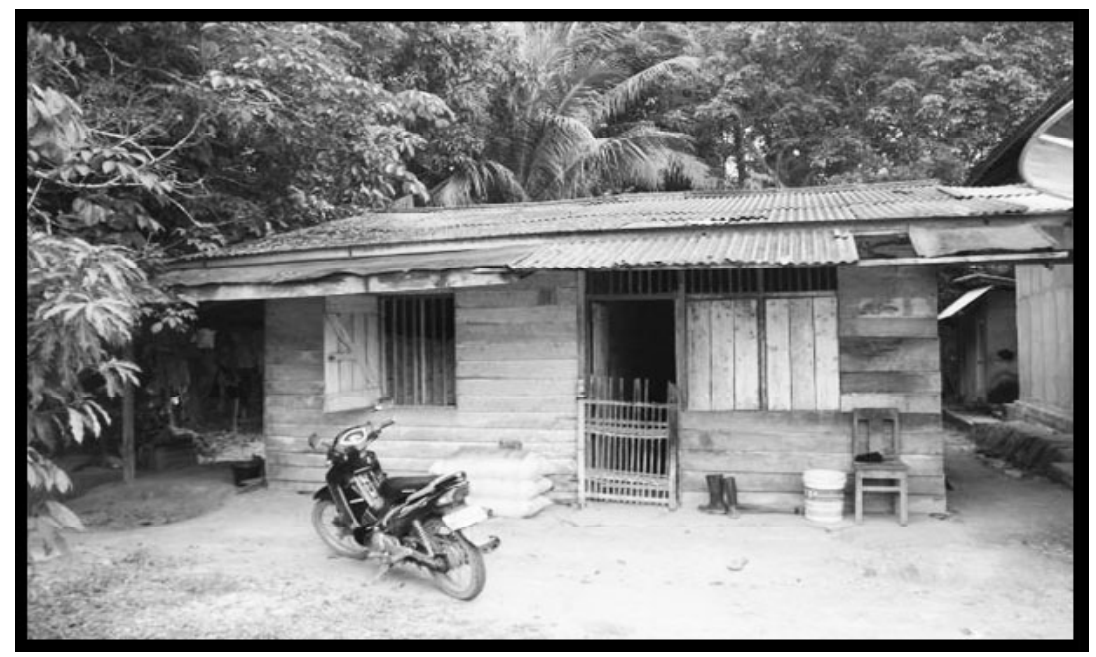

Sumber : Dokumen Pribadi 
Pola pemukiman yang didirikan oleh pemerintah saling berjauhan oleh karena itu ketika proses pembagian rumah pemerintah melakuan sistem pengundian. hal ini mendorong antara orang Bali dan Jawa bisa saling berdekatan.

Di samping memberikan perumahan pemerintah juga memberikan jatah hidup selama dua belas (12) bulan kepada setiap transmigran. Jatah hidup yang diberikan berupa sembako ( beras, minyak tanah, ikan teri, dan kacang-kacangan) untuk memenuhi kebutuhan hidup seharihari. Karena pemerintah merasa transmigran belum mampu untuk mencukupi kebutuhannya, maka pemerintah yang dibantu oleh jawatan transmigrasi memberikan bantuan lagi selama enam (6) bulan kepada transmigran berupa beras dan ikan kaleng. Namun jaminan yang diberikan pemerintah dirasa tidak cukup oleh warga maka dari itu uang tabungan yang dibawa oleh transmigran digunakan sebagai modal untuk berjual sayur untuk memenuhi kebutuhan hidup, beberapa diantara mereka menjual kayu bakar (Wawancara dengan Wayan Arjane di Bayat Ilir pada tanggal 13 Desember 2014).

Proses kedatangan orang Bali ke Mendis juga hampir sama dengan proses kedatangan orang Bali ke Bayat Ilir. Proses kedatangan mereka karena adanya kesempatan yang diberikan oleh pemerintah bagi masyarakat di Pulau Bali yang hidup dalam kondisi memperihatikan karena terbatasnya lahan yang mereka miliki. Rombongan orang Bali pertama kali datang ke Mendis sebanyak $25 \mathrm{KK}$ mereka berasal dari daerah Tabanan. Kehidupan awal mereka di Tabanan cukup memprihatikan sebab terbatasnya tanah yang mereka miliki menyebabkan mereka sulit untuk berkembang (Wawancara dengan Wayan Made di Mendis tanggal 12 Desember 2014).

Pemerintah melalui Jawatan Transmigrasi Tabanan menginvetarisasi seluruh masyarakat yang berada dibawah garis kemiskinan terutama di daerah pedesaan yang tidak bisa berkembang karena terbatasnya lahan yang mereka miliki. Informasi ini dipertegas oleh Bapak Wayan Made yang menjelaskan bahwa ketika masih di Tabanan beliau adalah seorang petani jeruk dan petani sawah. Terbatasnya lahan yang dimiliki oleh orang tua menyebabkan tidak semua anak bisa menjadikan tanah warisan orang tua sebagai tempat bercocok tanam. Kondisi ini mendorong dia bersama sang kakak mendaftar ke jawatan Transmigrasi untuk mendaftar sebagai peserta transmigrasi. Keingginan mereka untuk mendaftar didorong oleh informasi yang menjelaskan bahwa setiap tranmigran akan mendapatkan lahan sebanyak 2 Hektar dan Jatah hidup selama satu (1) tahun (Wawancara dengan Wayan Made di Mendis tanggal 12 Desember 2014).

Jalur yang mereka gunakan dari Bali ke desa Mendis tidak jauh berbeda dengan jalur kedatangan orang Bali ke Bayat ilir yaitu dari Pulau Bali ke Boom Baru di Kota Palembang setelah menginap selama satu malam rombongan transmigran diantar oleh pemerintah ke lokasi penempatan. Rombongan orang Bali di desa Mendis bersamaan datangnya dengan transmigran dari Jawa. Perbedaan mendasar antara orang Bali di Desa Mendis dan Bayat Ilir adalah jumlah Kepala Keluarganya jika di Bayat Ilir orang Bali dominan sedangkan di Desa Mendis jumlah orang Bali hanya $25 \mathrm{KK}$ sedangkan orang Jawa sebanyak $85 \mathrm{KK}$ (Wawancara dengan Wayan Made di Mendis tanggal 12 Desember 2014). 
Proses kedatangan Orang Bali ke kawasan Pangkalan Bayat jauh berbeda dengan Desa Mendis dan Bayat Ilir. Di kedua desa ini peranan pemerintah menjadi kata kunci dari berpindahnya orang Bali ke kawasan ini. Namun, di Pangkalan Bayat kehadiran orang Bali lebih disebabkan oleh upaya orang Bali menunjukan eksistensi dan keberadaan mereka di Bayung Lencir. Orang Bali yang berada di Pangkalan Bayat berasal dari berbagai daerah di Propinsi Sumatera Selatan, hal ini terungkap dari observasi lapangan yang dilakukan di kawasan tersebut.

Informasi dari Made Korser menjelaskan bahwa orang Bali di Pangkalan Bayat buka saja berasal dari Desa Mendis dari Desa Bayat Ilir, namun berasal dari perkampungan orang Bali di Lampung, Ogan Komering Ilir (OKI), Muara Enim dan Musi Rawas (Wawancara dengan Wayan Korser di Simpang Bayat tanggal 13 Desember 2014). Proses kedatangan mereka lebih disebabkan karena kemampuan dan kekuatan ekonomi yang mereka miliki menyebabkan munculnya keingginan dari sebagai orang Bali yang berada di daerah transmigrasi untuk mencari lokasi pemukiman di pinggir jalan yang memberikan kemudahan mereka untuk beraktifitas terutama bagi orang Bali yang memiliki minat sebagai pedagang (Wawancara dengan Wayan Korser di Simpang Bayat tanggal 13 Desember 2014).

\section{Gambar 8}

Wayan Korser Tokoh Masyarakat Bali di Pangkalan Bayat

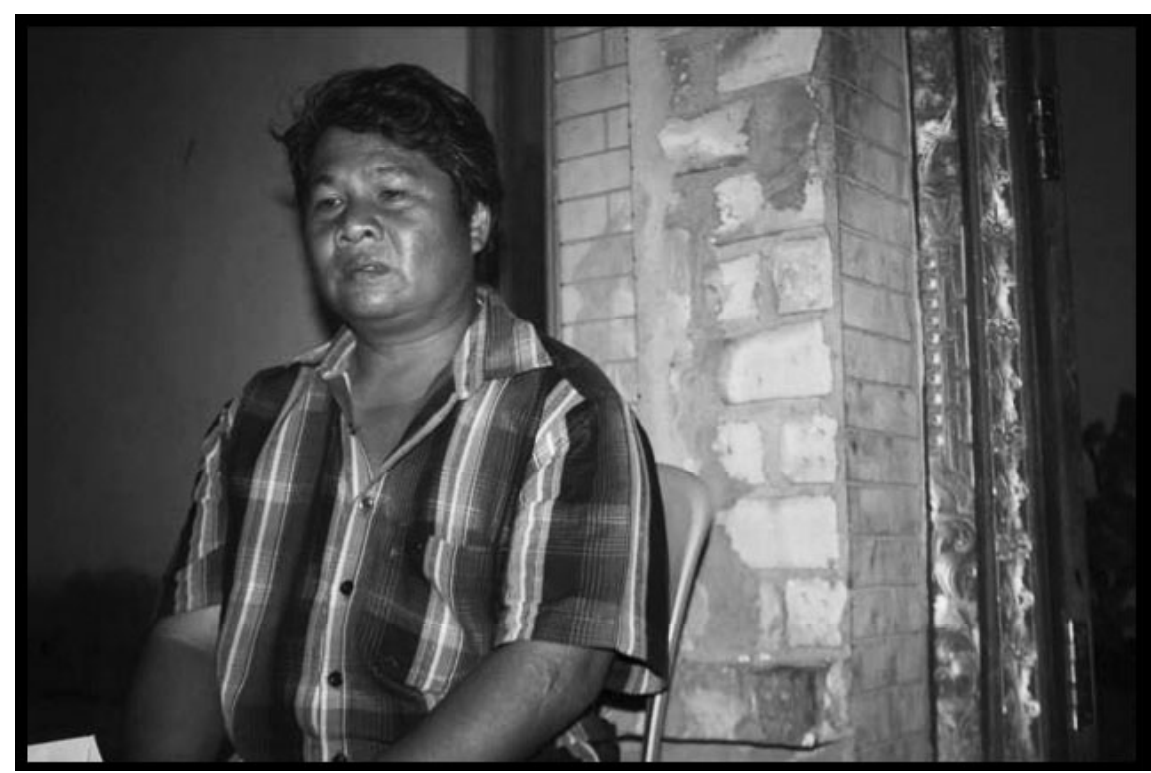

Sumber : Dokumen Pribadi

Proses mereka mendapat tanah di Pangkalan Bayat melalui proses jual beli antara pemilik tanah dengan orang Bali yang berminat tinggal di Pangkalan Bayat. Kehadiran kawasan ini sebagai lokasi pemukiman masyarakat Bali di Bayung Lencir baru terjadi pada tahun 1998, ketika harga getah meningkat dengan tajam sehingga meningkatkan taraf hidup orang Bali. Hal ini mendorong mereka untuk membeli tanah di pinggir jalan lintas Sumatera.

Cerita tentang proses kedatangan orang Bali ke Bayung lencir terlihat jelas ada perbedaan terutama bagi orang Bali yang tinggal di Desa Mendis dan Bayat Ilir dengan orang Bali yang berada di Pangkalan Bayat. Orang Mendis dan Bayat proses kehadiran mereka ke kawasan ini 
melalui proses yang panjang. Mulai dari pendaftaran hingga diberangkatkan ke lokasi penempatan. Orang Bali yang dipindahkan berasal dari berbagai daerah di Pulau Bali, bahkan ada orang Bali yang telah bermukim di Lampung, namun kembali mendaftar menjadi transmigrasi. hal ini mereka lakukan untuk mendapatkan kesempatan memperoleh lahan.

Jalur yang mereka gunakan untuk sampai ke lokasi adalah dari Bali dengan kapal laut hingga ke Palembang setelah itu melajutkan perjalanan ke lokasi penempatan dengan mengunakan mobil. Kondisi berbeda ditemukan pada kawasan orang Bali di Pangkalan Bayat kehadiran mereka adalah salah satu upaya orang Bali menunjukan eksistensi dan keberadaan mereka di Bayung Lencir. Umumnya perkampungan orang Bali berada di daerah pedalaman yang jauh dari jalan lintas. Kondisi ini mendorong orang Bali untuk mencari lokasi di pinggir jalan lintas sumatera, hal ini yang mendorong munculnya perkampungan Bali di Pangkalan Bayat. Akibatnya orang Bali di Pangkalan Bayat berasal dari berbagai perkampungan Bali di Sumatera Selatan.

\section{PENUTUP}

Kecamatan Bayung Lencir saat ini telah ditempati oleh masyarakat Bali, sebagai sebuah etnis atau suku bangsa, Bali memiliki perbedaan diantara etnis lainnya. Kehidupan masyarakat Bali di Bayung Lencir yang masih bertahan sebagai petani sawah seharusnya mendapatkan perhatian lebih dari pemerintah. Di tengah-tengah terbatasnya produksi beras dan kecenderungan petani sawah berpindah ke petani kebun akibat tidak sebandingnya harga jual gabah dan biaya produksi. Otonomi daerah menyebabkan munculnya semangat kedaerahan untuk itu pemerintah Pemerintah daerah melalui dinas-dinas terkait mesti melakukan berbagai upaya agar informasi tentang kepindahan masyarakat Bali ke Bayung Lencir, kehidupan masyarakat Bali dan proses mendapatkan lahan harus disampaikan pada generasi muda untuk mengindari konflik di kemudian hari. Untuk itu diharapkan pemerintah harus melakukan berbagai langkah diantaranya :

1. Menerbitkan Buku yang mengungkapkan proses kedatangan, pemberian lahan dan kehidupan awal masyarakat Bali di Bayung Lencir atau Musi Banyuasin umumnya sebagai bahan bacaan untuk masyarakat asli terutama generasi muda untuk membangun kesadaran mereka tentang masyarakat Bali.

2. Memberikan bantuan dan pelatihan kepada orang Bali dalam mempertahankan identitas budaya yang mereka miliki dalam rangka memberi warna dalam kehidupan masyarakat.

3. Melengkapi infrastruktur penunjang untuk mengoptimalkan untuk meningkatkan kehidupan masyarakat Bali di Bayung Lencir.

4. Menfasilitasi terciptanya event-event yang mendukung terciptanya interaksi antara masyarakat Jawa, Bali dan etnis lainnya secara alami.

5. Pemerintah Daerah perlu mengadakan festival-festival yang menampilkan budaya dan keunikan masing-masing etnis di Musi Banyuasin untuk mengungkapkan kekayaan budaya di Musi Banyuasin 


\section{DAFTAR PUSTAKA}

\section{Buku dan Laporan}

Apriansyah, 2000 “ Kelompok-Kelompok Etnis Tranmigrasi Dalam Pengembangan Kelembagaan Dan Pengelolaan Air Di Lahan Pasang-Surut ( Studi Kasus Dua Komunitas Petani Beririgasi Sederhana dan Teknis di Unit Pemukiman Transmigrasi, Kalimantan Selatan) Tesis Bogor : Pascasarjana Universitas Pertanian Bogor.

Ajisman dan Rois Leonard Arios, 2012. "Transmigrasi dan Adaptasi Studi Kasus Orang Bali di Desa Nusa Bali Kabupaten Ogan Komering Ulu Timur (OKUT) Sumatera Selatan”. Laporan Penelitian Padang : BPSNT Padang,

Charras, Muriel 1997 “ Dari Hutan Angker Hingga Tumbuhan Dewata. transmigrasi di Indonesia: Orang Bali di Sulawesi. Yogyakarta : Gadjah Mada University Press.

Diansyah, Novry Baru, 2008 "Dari Kontrak Kerja Membentuk Sebuah Komunitas; Studi Kasus Masyarakat Hindu Bali di Desa Pegajahan Kecamatan Perbaungan (1963-1990)" Skripsi Medan : fakultas Sastra Univeristas Sumatera Utara.

Sudiana I Made (TTT) " Eksistensi Bahasa Bali Di Daerah Eks Transmigrasi Dataran Dumoga, Bolaang Mongondow, Sulawesi Utara" artikel Denpasar :Balai Bahasa Denpasar.

Kamus Besar Bahasa Indonesia Pusat Bahasa, Jakarta: Diknas dan Gramedia Pusaka Utama 2008 Koentjaranigrat, 2006 " Pengatar Antropologi “ Jakarta : Aksara Baru.

Kartodirdjo, Sartono 1992 Pendekatan Ilmu Sosial Dalam Metodologi Sejarah. Jakarta: PT Gramedia Pustaka Utama.

Panitia Kegiatan Jelajah Budaya, 2012 "Laporan Kegiatan Jelajah Budaya BPSNT Padang tahun 2012 di Arga Makmur Kabupaten Bengkulu Utara Propinsi Bengkulu”. Padang : Balai Pelestarian Sejarah dan Nilai Tradisional.

Louer, Robert H. 2003 Perspektif tentang Perubahan Sosial, Jakarta Rineka Cipta.

Meirani Harsasi “Organisasi Multibudaya Dan Pelatihan Tentang Keberagaman” dalam jurnal Organisasi dan Manajemen, Volume 4, Nomor 1, Maret 2008.

Nugraha, Andri, 2013 "WUKU; Kearifan Lokal Penanggalan Musim Dalam Kegiatan Pertanian Pada Orang Bali di Pegajahan” skripsi Medan: Universitas Sumatera Utara.

Notosusanto, Nugroho 1984. Masalah Penelitian Sejarah Kontemporer, Jakarta: Inti Idayu Press

Soekanto, S 2001 Sosiologi Suatu Pengantar. Jakarta: Raja Grafindo

Saleh, Harry Hariawan, 2005 Transmigrasi : antara kebutuhan masyarakat dan kepentingan pemerintah. Jakarta : Pustaka Sinar Harapan.

MS, Wahyu. 2005 “Perubahan sosial dan Pembangunan”, Jakarta: Hecca Mitra Utama,

\section{Website}

Beritabali.com “ Sejarah Letusan Gunung Agung” diposkan pada hari Sabtu, 06 Agustus 2012 diakses dari www.beritabali.com pada tanggal 26 Juli 2013

Berita Satu.com "Bentrok di Lampung, Pemuda Bali Serukan Penghentian Konflik" diposkan pada tanggal 31 Oktober 2012 diakses dari www.beritasatu.com pada tanggal 26 Juli 2013

Profil Balai Wilayah Sungai Bali- Penida http://www.pu.go.id/satminkal/dit_sda/profil\% 20balai/bws/ profilebalaibalipenida diakses tanggal 26 Juli 2013

www.hukumonline.com/pusatdata/download diakses tanggal 26 Juli 2013

http://www.baliprov.go.id/ diakse tanggal 26 Juli 2013. 